УДК 331.58:331.445:331.108.2

\author{
Мокіна С.М. \\ аспірант \\ кафедра менеджменту \\ sofia.mokina@gmail.com \\ Національний університет харчових технологій \\ вул. Володимирська, 68, м. Київ, Україна, 01601
}

\title{
ЕВОЛЮЦІЯ ФОРМУВАННЯ КОНЦЕПЦІЇ БРЕНДУ РОБОТОДАВЦЯ
}

В статті проведено дослідження еволюції формування концепції бренду роботодавця. Визначено, що концепція бренду роботодавця є міждисциплінарною. Автором виділено три основні концепції, в результаті розвитку яких сформувалась концепція бренду роботодавця - концепція брендингу, маркетингу та управління персоналом. В статті детально структуровано генезис концепції брендингу роботодавця.

Ключові слова: бренд роботодавця, концепція бренду роботодавця, поняття бренду роботодавця, еволюція бренду роботодавця.

Постановка проблеми та її зв'язок 3 важливими науковими та практичними завданнями. Інтерес до брендингу роботодавця серед українських компаній значно зріс протягом останніх п'яти років, цей факт обумовлений тенденціями розвитку світової економіки. Світові ринки стають більш складними, конкуренція посилюється не тільки на товарних ринках, а й на ринку праці. До недавнього часу в українській економічній науці поняття «бренд роботодавця» практично не використовувалось і замінювалось більш вузьким поняттям «імідж роботодавця». Тому вітчизняні підприємства намагаються заповнити існуючу прогалину на практиці, копіюючи західні технології роботи з брендом роботодавця, що не завжди виправдано в українських ринкових умовах. В даних умовах детальне наукове та практичне вивчення концепції бренду роботодавця, здатної дати підприємству додаткову конкурентну перевагу на ринку праці, є особливо важливим і актуальним для українських підприємств.

Аналіз останніх публікацій по проблемі. Питанню розробки бренду присвячені в основному роботи зарубіжних авторів - Д. Аакера, Ф. Котлера, Д. Ле Пла, П. Темпорао, Е. Райса, Х. Прінгла, Т. Нільсона, Б. Барнса, Б. Ванекена, А. Вілера, А. Еллвуда, Е. Йохімштайлера, Ж.-Н. Капферера, К.Л. Келлера, Д. Коулі, С. Кумбера, У. Лендора, М. Ліндстрома, Дж. Маріотті, Т. Нільсона, Дж. Ренделла, Дж. Траута, П. Фернандеса, Р. Шоу, Д. Шульца та ін.

Серед українських науковців питання, що стосуються брендингу, викладені у працях: А. Войчака, Т. Дібрової, О. Зозульова, О. Кендюхова, О. Кістеня, О. Ляшенко, А. Мелетинської, О. Пестрецової, В. Пустотіна, Г. Рябцева, А. Старостіної, Р. Федоровича, А. Федорченка та ін.

Питання внутрішнього брендингу, інструменти якого використовують для управління персоналом, дослі- джували Т. Амблер, П. Баклі, К. Пунджаірсі, А. Уілкінсон, С. Хардінг.

Питання внутрішнього маркетингу персоналу досліджують М. Рафік, П.К. Ахмед, К. Лавлок, Е. Гуммессон, К. Гренрус та інші.

Концепція бренду роботодавця висвітлена в роботах Б. Мінчінгтона, Р. Мослі, П. Бертона, М. Евінга, Л. Хаха, Г. Мартіна, С. Хетріка, К. Бакхауса, С. Тікоо та інших.

Формулювання цілей дослідження. Мета статті дослідити еволюцію розвитку концепції бренду роботодавця, проаналізувати думки зарубіжних та вітчизняних вчених 3 цього питання, сформулювати авторський підхід до розуміння походження концепції бренду роботодавця.

Виклад основних результатів та їх обгрунтування. В процесі еволюції поняття брендингу пройшло декілька етапів, які характеризують його з різних сторін.

На першому етапі брендинг був виключно прикладною діяльністю, яка направлена на формування конкурентних переваг компаній, що функціонують в умовах жорсткої конкуренції. Для цього етапу характерним була відсутність єдиного підходу до розуміння і визначення брендингу і бренду. Так, ще в XIV ст. в Свропі з'явилися перші товарні знаки - клейма, якими ремісники таврували свої вироби, відзначаючи тим самим виняткову якість товару і приналежність до певного майстра. Перші спроби систематизувати знання про брендинг були здійснені в 20-х pp. ХХ ст. в США. Саме тоді почала складатися концепція бренд-менеджменту, мається на увазі не лише створення і просування товарного знаку, а й управління брендами як нематеріальними активами компанії. Концепція бренд-менеджменту дозволяла розробити для брендів окремі маркетингові стратегії і проводити комплексні рекламні кампанії з просування цих марок [1]. 
Під терміном «бренд» прийнято розуміти впізнаваний споживачем торговий знак або марку, а під «брендингом» - процес створення і розвитку (тобто управління) брендом. Однак Ф. Котлер у своєму підручнику дає досить повне визначення брендингу: «Брендинг - це наділення товарів і послуг силою торгової марки... Брендинг включає в себе створення ментальних структур, які допомагають споживачам в отриманні знань про товар або послугу таким чином, щоб полегшити прийняття рішення про покупку, вигідну для компанії» [2]. Девід Аакер одним $з$ перших визначив бренд як інструмент управління, за допомогою якого можна керувати діяльністю всієї організації. Бренди стали могутньою зброєю, комерційною силою, вони беруть участь у формуванні та підтримці стосунків, комунікаціях в системі «виробникторговий посередник - інвестор - покупець (споживач)». Тим самим бренд, поряд з такими атрибутами, як орієнтація на довгострокові відносини, задоволеність, збереження і територіальна близькість покупця, стає найважливішою характеристикою цінності покупця [3].

В даний час в теорії та практиці маркетингу брендменеджмент виділився в самостійну дисципліну і став предметом пильної уваги як зарубіжних, так і вітчизняних вчених. Закордонний розвиток бренд-менеджменту та брендингу активно почався в 70-80 pp. ХХ ст. Представниками західної школи в теорії брендингу і брендів стали: Девід Аакер [4] і Ерік Йохімштайлер [5], які зробили внесок у вивчення питань бренд-лідерства як нової концепції бренд-менеджменту; Джек Траут та Е. Райс, [6], які займались питаннями позиціонування брендів; Томас Гед, що розробив концепцію «4D брендингу» [7].

Т. Амблер відмічає, що поняття «бренд», яке раніше використовувалось для споживчих товарів, тепер може застосовуватись для будь-якої сфери; в теперішній час воно включає цілий ряд переваг для кінцевого користувача [8]. Подібні думки висловлюють і Ф. Котлер та К. Келлер: «Брендинг можна застосувати практично до всього, що пропонується споживачу на вибір. До товару... послуги... магазину... людини... організації...» [2].

Цю ж точку зору поділяє П. Баклі. Він зазначає, що успішні компанії змінили акцент з брендингу продукції на брендинг компаній, що дозволяє створювати ренту для всієї продукції компанії. Таким чином, цінності і культура компанії перетворюються на унікальну торгову пропозицію для всіх іiї товарів та послуг [9].

В подальшому загострення конкурентної боротьби та орієнтація на конкретний ринковий сегмент стали причиною формування бренду як відгуку на реакцію споживачів щодо конкретних товаровиробників і товарів. В цей же час брендинг набуває ознак багатогранного поняття. Брендинг став міждисциплінарним поняттям, акцент змістився з розгляду товарів чи послуг на організацію, особистість, діяльність. Розглядаючи бренд організації Д. Аакер використовує поняття «корпоративний бренд» і підкреслює необхідність зосередження уваги на організаційних цінностях, культурі, комунікаціях, працівниках, які створюють позитивні асоціації і можуть бути джерелом конкурентних переваг компанії [4]. Про те, що працівники можуть бути конкурентною перевагою корпоративного бренда компанії, зазначає також Л. Де Чернатоні [10]. Розкриваючи такі інструменти корпоративного брендингу, як корпоративна культура для поєднання співробітників, проектування бажаної поведінки працівників на основі цінностей і місії компанії, Л. Де Чернатоні підкреслює, що ключова роль у формуванні корпоративного бренду належить відділу з управління персоналом: «При корпоративному брендингу співробітники не тільки здійснюють суттєвий внесок в цінності бренду, вони також подають сигнал про оцінку бренду. В цьому випадку керівник відділу з управління персоналом повинен сприйматись, як основний член брендкоманди, оскільки він розроблює політику, що впливає на побудову бренду, а саме - програми найму персоналу, адаптації нових працівників, навчання та винагородження» [11]. Отже, використання концепції корпоративного брендингу поширюється і на брендинг персоналу, тобто внутрішній брендинг.

Підвищення соціальної відповідальності власників i менеджменту стало причиною того, що співробітники компаній почали розглядатись як клієнти, на задоволення потреб яких також була спрямована діяльність копаній.

В науковій літературі розглядають внутрішній та зовнішній брендинг. Внутрішній брендинг передбачає побудову внутрішніх бізнес-процесів і організаційної культури, що не суперечать корпоративному бренду. Ціль внутрішнього брендингу полягає в підготовці організацією таких співробітників, які здатні передавати клієнтам та іншим стейкхолдерам повідомлення, закладені в бренді. Це означає, що успіх внутрішнього брендингу залежить від ступеня прихильності, лояльності працівників до бренду та ідентифікації з ним [12]. Прихильниками концепції внутрішнього брендингу як частини концепції корпоративного брендингу є К. Пунджаірсі та А. Уілкінсон. Вони вважають, що використання принципів внутрішнього брендингу допомагає компанії узгоджувати поведінку співробітників з цінностями, закладеними в бренді: «Внутрішній брендинг - це спосіб створення сильних корпоративних брендів» [13].

Поряд 3 концепцією внутрішнього брендингу у 70их роках XX ст. набуває поширення концепція внутрішнього маркетингу. Леонард Беррі у 1976 році вперше використав термін «внутрішній маркетинг». За підтримки 
колеги, А. Парасурамана, вчений започаткував філософію «ставлення до працівника як до внутрішнього клієнта» та спрямував увагу на працю в організації як на певний продукт [14]. Дана теза знайшла поширення та розвиток у працях інших американських науковців, які сформували взаємозв'язок «задоволеність клієнта - задоволеність працівника» та обгрунтували важливість мотивації персоналу. К. Лавлок підкреслює важливість внутрішнього маркетингу та визначає його істотним фактором успіху для компаній галузі послуг [15].

Англійські вчені М. Рафік та П.К. Ахмед дають визначення внутрішнього маркетингу, як планомірної діяльності з подолання опору персоналу змінам, регулювання, мотивації та інтеграції працівників з метою ефективної реалізації корпоративних та функціональних стратегій. Вони вважають, для того, щоб компанія мала задоволених клієнтів, вона також повинна мати задоволених працівників, тобто, робота як продукт повинна створювати мотивований та клієнтоорієнтований персонал, заохочувати, розвивати працівників, задовольняючи їх потреби [16].

Найбільш значний внесок в розвиток концепції внутрішнього маркетингу здійснили засновники Скандинавської школи маркетингу послуг Е. Гуммессон та К. Гренрус, які вперше використали терміни «внутрішній продукт» та «внутрішній споживач», маючи на увазі роботу та персонал фірми відповідно. Е. Гуммессон висвітлює важливість працівників, які беруть участь у процесі маркетингу, але працюють за межами маркетингового відділу - «маркетологи за сумісництвом», Е. Гуммессон вважає, що працівники є первинним ринком для будьякої компанії, i їхня робота 3 клієнтами буде бездоганною лише у випадку, коли потреби працівників будуть задоволені [17].

На думку Стефана Хардінга, концепція бренду роботодавця походить 3 концепції внутрішнього маркетингу. Вона допомагає компанії підтримувати свою ідентичність 3 трьох позицій на ринку: як хорошого роботодавця для наявного персоналу, як привабливого роботодавця для потенційних працівників та як постачальника чи партнера для клієнтів [18].

Бренд роботодавця - це процес позиціонування образу компанії як найкращого місця для роботи в думках цільової групи кандидатів [19].

Дж. Салліван порівнює бренд роботодавця з товарним брендом. Товарний бренд формує довготривалий образ товару в думках споживачів, за допомогою якого автоматично при контакті з будь-яким товаром даного бренду виникають асоціації з певними цінностями та перевагами товару. Бренд роботодавця, на думку Дж. Саллівана, має таку ж функцію, тобто створює образ та асоціації у працівників, що вони однозначно хочуть працювати в компанії, оскільки компанія має сильне керівництво та розвинені програми навчання та розвитку. Сильний бренд роботодавця забезпечує постійний потік кандидатів в компанію. Бренд роботодавця використовує інструменти маркетингових досліджень, PR, реклами, щоб затвердити образ компанії як «найбажанішого місця роботи» в свідомості кандидатів [19].

Отже, відповідно до концепції внутрішнього маркетингу персонал компанії можна розглядати в якості внутрішнього цільового ринку, розподіляючи його на сегменти, щоб вивчати особливості кожного сегмента окремо. Задоволення робочих потреб співробітників здійснюється за підсумками проведених досліджень. А співробітники взамін працюють, забезпечуючи високі стандарти обслуговування зовнішніх споживачів.

Виділення концепції управління персоналом в окрему площину вивчення дозволило змінити погляди науковців на людину, їі місце в організації й оптимальні важелі впливу. Акцент змінився з людини як ресурсу виробничої системи, важливого елементу процесу виробництва і управління на людину як особистість з іï потребами, мотивами, цінностями як головного суб'єкта управління.

Становлення і розвиток ринкової економіки в переважній більшості розвинутих країн та країн, що розвиваються супроводжувались появою більшої кількості комерційних організацій та інтенсифікацією конкуренції між ними. Поява нових компаній призвела до появи нових робочих місць. Таким чином, виріс попит на трудові ресурси. Однак несприятливі демографічні тенденції, що обумовили зниження кількості працездатного населення, викликали дисбаланс між попитом та пропозицією трудових ресурсів на ринку праці. В умовах висококонкурентного ринку праці, що характеризується перевищенням попиту на трудові ресурси над їх пропозицією, дефіцитом кваліфікованого персоналу, високим ступенем мобільності співробітників, зниженням лояльності персоналу до роботодавця, необхідною умовою виживання і динамічного розвитку компанії стає можливість залучення нових і утримання працюючих співробітників. Виникла необхідність в пошуку нових, більш ефективних інструментів залучення та утримання персоналу, щоб отримати перемогу в «битві за персонал». Тому, у зв'язку з актуалізацією міждисциплінарних досліджень на стику маркетингу і управління людськими ресурсами в середині 1990-х рр. сформувалась концепція бренду роботодавця [12].

В таблиці 1 нами узагальнена еволюція передумов виникнення бренду роботодавця. В результаті проведеного аналізу передумов виникнення бренду роботодавця, можна вважати, що концепція бренду роботодавця 
Таблиця 1

Еволюція формування концепції бренду роботодавця

\begin{tabular}{|c|c|c|c|}
\hline Рік & Концепції маркетингу & Концепції брендингу & Концепції управління персоналом \\
\hline $\begin{array}{c}1860- \\
1920 \text { pp. }\end{array}$ & $\begin{array}{l}\text { Виробнича концепція } \\
\text { *налагодження виробництва } \\
\text { для збільшення обсягу випуску } \\
\text { продукції вже існуючого } \\
\text { асортименту в умовах товарного } \\
\text { дефіциту; } \\
\text { * оптимізація виробничих затрат. }\end{array}$ & $\begin{array}{l}\text { Ідентифікаційний брендинг } \\
\text { *при позиціонуванні акцент } \\
\text { на продукт/сервіс; } \\
\text { * виділення продуктової } \\
\text { категорії; } \\
\text { *функція - безпечність, } \\
\text { акцент на якість, склад і ціну. }\end{array}$ & \multirow[t]{2}{*}{$\begin{array}{l}\text { Управління кадрами } \\
\text { (економічний підхід) } \\
\text { *робітник розглядається як носій трудової } \\
\text { функції, живий «додаток машини»; } \\
\text { *відбір здібних працівників, стимулювання, } \\
\text { нормування праці; } \\
\text { *підвищення продуктивності праці для } \\
\text { більшого випуску продукції; }\end{array}$} \\
\hline $\begin{array}{c}1920- \\
1930 \text { pp. }\end{array}$ & $\begin{array}{l}\text { Товарна концепція } \\
\text { *вдосконалення якостей товару } 3 \\
\text { метою стимулювання попиту } \\
\text { *випуск нових товарів, модернізація } \\
\text { та підвищення якості існуючих } \\
\text { товарів. }\end{array}$ & $\begin{array}{l}\text { Брендинг вигод } \\
\text { *унікальна торгова } \\
\text { пропозиція (УТП), виділення } \\
\text { якостей товару та вигод від } \\
\text { товару. }\end{array}$ & \\
\hline $\begin{array}{c}1930- \\
1960 \text { pp. }\end{array}$ & $\begin{array}{l}\text { 3бутова концепція } \\
\text { *організація ефективної служби } \\
\text { просування та збуту для збільшення } \\
\text { об’єму продаж в умовах, коли } \\
\text { пропозиція товарів перевищила } \\
\text { попит; } \\
\text { *використання агресивних методів } \\
\text { реклами та стимулювання збуту. }\end{array}$ & $\begin{array}{l}\text { «Символічний» брендинг } \\
\text { *при позиціонуванні акцент } \\
\text { на імідж користувача/ } \\
\text { покупця, цінності, життєвий } \\
\text { стиль } \\
\text { *персоналізація, особистість. }\end{array}$ & \multirow{2}{*}{$\begin{array}{l}\text { Управління персоналом } \\
\text { *робітник розглядається як суб’єкт трудових } \\
\text { відносин, особистість; } \\
\text { *ускладнюється механізм трудової } \\
\text { мотивації з переорієнтацією його на } \\
\text { творчість, підвищення кваліфікації; } \\
\text { *часткове управління життєвим циклом } \\
\text { працівника; } \\
\text { *створюється система безперервного } \\
\text { професійного навчання; } \\
\text { *розвивається соціальне партнерство; } \\
\text { *підвищується роль організаційної } \\
\text { культури; } \\
\text { Людина розглядається як елемент } \\
\text { організації, суб’єкт трудових відносин. }\end{array}$} \\
\hline $\begin{array}{c}1960- \\
1980 \text { pp. }\end{array}$ & $\begin{array}{l}\text { Традиційний (чистий) маркетинг } \\
\text { *орієнтація на отримання прибутку } \\
\text { за рахунок задоволення особистих } \\
\text { потреб споживачів; } \\
\text { *акцент на задоволення потреб } \\
\text { цільових ринків. }\end{array}$ & $\begin{array}{l}\text { Брендинг «досвіду» } \\
\text { *досвід споживача; } \\
\text { *мультисенсорний брендинг } \\
\text { (вигляд, звук, смак, запах, } \\
\text { тактильні відчуття, почуття, } \\
\text { думки). }\end{array}$ & \\
\hline $\begin{array}{c}1980- \\
1990 \text { pp. }\end{array}$ & $\begin{array}{l}\text { Соціально-відповідальний } \\
\text { (соціально-етичний маркетинг) } \\
\text { *задоволення потреб споживачів } \\
\text { цільових ринків з врахуванням } \\
\text { потреб суспільства, за умов } \\
\text { збереження людських, матеріальних, } \\
\text { енергетичних ресурсів, охорони } \\
\text { навколишнього середовища. }\end{array}$ & $\begin{array}{l}\text { «Соціальний» брендинг } \\
\text { *бренд почав враховувати } \\
\text { соціальну складову, соціальну } \\
\text { відповідальність. }\end{array}$ & $\begin{array}{l}\text { Управління людським ресурсами } \\
\text { *робітник розглядається як ключовий } \\
\text { стратегічний ресурс компанії; } \\
\text { * Навчання персоналу - поглиблення } \\
\text { як спеціалізації, так і універсалізації, } \\
\text { створення умов для максимальної } \\
\text { самоорганізації співробітників; } \\
\text { *комплексне управління життєвим циклом } \\
\text { працівника. }\end{array}$ \\
\hline $\begin{array}{c}1990 \text { - до } \\
\text { тепер }\end{array}$ & $\begin{array}{l}\text { Маркетинг відносин } \\
\text { *задоволення потреб клієнтів, } \\
\text { партнерів, держави в процесі } \\
\text { взаємодії; } \\
\text { * в основі плідної співпраці лежать } \\
\text { взаємоповага, взаєморозуміння, } \\
\text { взаємодовіра, врахування інтересів } \\
\text { усіх сторін, що беруть участь у } \\
\text { процесі, та максимальне укріплення } \\
\text { індивідуальних відносин. }\end{array}$ & $\begin{array}{l}\text { «Тотальний» брендинг } \\
\text { *не тільки інструмент } \\
\text { маркетингу, але і бізнес- } \\
\text { стратегія; } \\
\text { *інтегрована система } \\
\text { фізичних, психологічних, } \\
\text { соціальних компонентів на } \\
\text { базі ідеології. }\end{array}$ & $\begin{array}{l}\text { Гуманістична концепція } \\
\text { *не люди для організації, а організація для } \\
\text { людей; } \\
\text { *людина - член корпоративної «родини»; } \\
\text { *адаптація, якість трудового життя, розвиток } \\
\text { культури організації - створення цінностей, } \\
\text { формування правил і норм, символізація; } \\
\text { *чим глибше люди розділяють цінності, тим } \\
\text { легше направляти їх; } \\
\text { *самоменеджмент «я повинен поступати так»; }\end{array}$ \\
\hline
\end{tabular}

Виникнення концепції бренду компанії як роботодавця в рамках концепцій внутрішнього маркетингу, брендингу та управління персоналом: *бренд роботодавця та брендинг на ринку праці - найменш розроблений і опрацьований розділ концепції внутрішнього маркетингу [20; 21]; *бренд роботодавця - теорія «внутрішнього брендингу», складова концепції корпоративного брендингу [22]; *бренд роботодавця - пов’язаний з еволюцією теорії психологічного контакту і тим впливом, який психологічний контакт здійснює на організаційні відносини [23]. Розроблено автором на основі [24-27].

виникла на підставі розвитку концепцій внутрішнього маркетингу, брендингу та управління персоналом. Всі три концепції певний період часу розвивались відокремлено одна від одної і лише на етапі виділення соціаль- ного аспекту даних концепцій як найбільш важливого (1980-1990-ті роки), відбувається взаємопроникнення і взаємозбагачення цих концепцій, що втілилось у сучасній концепції бренду роботодавця. 
В цілому тенденції управління людьми в організаціях носять глобальний характер і відображають пошуки передових компаній у створенні високоефективних систем реалізації творчого і продуктивного потенціалу 3 метою підвищення ефективності діяльності компанії. Чітке розуміння і практичне застосування принципів концепції бренду роботодавця, заснованих на формуванні, підтримці і позиціонуванні унікального образу компанії як роботодавця на ринку праці, привабливого як для потенційних, так і наявних працівників, дає можливість компанії успішно функціонувати в умовах так званої війни за таланти.

3 огляду на те, що відбувався розвиток теорій управління персоналом, підприємства еволюціонували, відбувалась трансформація визначення поняття «бренд роботодавця».

Вперше термін «еmployer brand» був представлений управлінській спільноті Саймоном Берроу (Simon Barrow), президентом People in Business, на щорічній конференції Королівського інституту розвитку персоналу у Великобританії (CIPD) в 1990 році і дослівно в перекладі 3 англійської мови означає «бренд роботодавця» [28]. Пізніше термін був визначений Саймоном Берроу спільно 3 Тімом Амблером (Tim Ambler), старшим науковим співробітником Лондонської школи бізнесу в статті в Journal of Brand Management, що вийшла в грудні 1996 року [29]. Ця академічна публікація стала першою спробою випробувати можливість застосування методів бренд-менеджменту до управління людськими ресурсами. Для цього Амблер і Берроу провели напівструктуровані інтерв'ю $з$ представниками 27 компаній про значущість бренду в управлінні людськими ресурсами. Вони прийшли до висновку, що брендинг має значення в контексті працевлаштування. У цій публікації Берроу і Амблер представили перше визначення бренда роботодавця: «набір функціональних, психологічних та економічних переваг, що надаються роботодавцем працівнику і ототожнюються з ним» [29].

До цього поняття брендингу компанії для потенційних и теперішніх працівників фігурувало в літературі 3 маркетингу [30].

Поступово бренд роботодавця стає невід'ємним атрибутом крупних компаній, а відтоді і об'єктом дослідження науковців. В розвитку бренду роботодавця власники і менеджмент вбачають можливість надбання і утримання конкурентних переваг.

До 2001 року із 138 лідируючих компаній, опитаних Conference Board у Північній Америці, 40 \% стверджували, що активно займалися розвитком свого бренду як роботодавця. У звіті про дослідження бренду роботодавця Conference Board у 2001 році зазначено, що організації зрозуміли, ефективний бренд роботодавця надає конку- рентні переваги, допомагає співробітникам перейняти корпоративні цінності та сприяє ефективному утриманню персоналу [31].

У 2003 році журналом The Economist було проведене дослідження серед широкого кола читачів, яке виявило 61\%-вий рівень обізнаності про термін «етployer brand» серед фахівців з управління людськими ресурсами та 41\%-вий рівень обізнаності у неспеціалістів [32].

Перша книга, присвячена розвитку бренду роботодавця, вийшла в 2005 році під авторством Саймона Берроу і Річарда Мослі та була названа «The Employer Brand: Bringing the Best of Brand Management to People at Work» («Бренд роботодавця: застосування [всього самого] кращого з бренд-менеджменту до працівників»). У ній автори вивчають причини появи поняття «employer brand», а також звертають увагу на його історичні корені, які походять 3 розвитку бренд-менеджменту. Крім того, автори звертають увагу на практичні кроки, необхідні для досягнення успіху в управлінні брендом роботодавця [33].

3 часом розвиток бренду роботодавця стає невід'ємною складовою стратегічного розвитку підприємств. У подальшому створення та розвиток бренду роботодавця стає окремим видом діяльності, за допомогою якого формується позитивний імідж компанії на ринку праці, підвищується конкурентоспроможність компанії як роботодавця, забезпечується високий рівень лояльності співробітників.

Висновки та перспективи подальших досліджень. Відповідно до поставленої мети в статті було досліджено еволюцію формування концепції бренду роботодавця. Концепція бренду роботодавця сформувалась у 90-их роках ХХ ст. в умовах висококонкурентного ринку праці, що характеризувався перевищенням попиту на трудові ресурси над їх пропозицією, дефіцитом кваліфікованого персоналу, високим ступенем мобільності співробітників, зниженням лояльності персоналу до роботодавця. Бренд роботодавця допомагає компанії бути конкурентоспроможною на ринку праці в таких умовах. Концепція бренду роботодавця є міждисциплінарною та виникла на перетині декількох концепцій - корпоративного брендингу, внутрішнього брендингу, внутрішнього маркетингу та управління персоналом.

В результаті проведеного аналізу передумов виникнення бренду роботодавця, можна вважати, що концепція бренду роботодавця виникла на підставі розвитку концепцій внутрішнього маркетингу, брендингу та управління персоналом.

Розвиток концепції бренду роботодавця досягнув такого рівня в світі, що тепер це невід'ємна частина бізнес-стратегії компанії.

Подальші дослідження будуть спрямовані на уточнення понятійного апарату концепції бренду роботодавця, функцій, методів та інструментів формування. 


\section{Література}

1. Домнин В. Н. Брендинг: новые технологии в России / В. Н. Домнин. - СПб. : Питер, 2004. - 250 с.

2. Котлер Ф. Маркетинг менеджмент / Ф. Котлер, К. Келлер. - СПб. : Питер, 2006. - 12-е изд. - С. 304.

3. Боброва Е. А. Проблемы формирования и развития конкурентоспособного бренда в условиях экономики впечатлений / Е. А. Боброва, О. У. Юлдшева, И. Ю. Окольнишникова // Вестник удмуртского университета. - 2011. - № 1.

4. Аакер Д. Створення сильних брендів / Д. Аакер. - М. : Видавничий дім Гребеннікова, 2003.

5. Aaker D., Joachimsthaler E. Building brands without mass media / E. Joachimsthaler, D. Aaker // Harvard business review. -75 (1). - P. 39-52. - 1997.

6. Ries A., Trout J. Positioning: The Battle for Your Mind / A. Ries, J. Trout. - McGraw-Hill; 1 edition. - 2000.

7. Гед Т. «4D брендинг: взламывая корпоративный код» / Т. Гед. - СПб : Издательство : Стокгольмская школа экономики в Санкт-Петербурге, $2001-230$ с.

8. Ambler T. Marketing Metrics / T. Ambler // Business Strategy Review. - 2000. - Vol. 11. - N 2. - P.59-66.

9. Баклі П. Дж. Глобальна фабрика: нова концепція / П. Дж. Баклі // Російський журнал менеджменту. - 2008. - Т.6. - № 1. C.135-154.

10. De Chernatony L. Brand management through narrowing the gap between brand identity and brand reputation / L. de Chernatony // Journal of Marketing Management. - 1999. - Vol. 15, № 1-3. - P.157-180.

11. Де Чернатоні Л. Від бачення бренду до оцінки бренду. Стратегічний процес росту і посилення бренду / Л. Де Чернатоні. М. : Група ІДТ, 2007. - С.47.

12. Кучеров Д. Г. Бренд роботодавця: область маркетингу чи управління людськими ресурсами? / Д. Г. Кучеров // Вісник СПбГУ. - 2009. - Сер. 8. - Вип. 3.

13. Punjaisri K. The Role of Internal Branding in the Delivery of Employee Brand Promise / K. Punjairsi, A. Wilkinson // Brand Management. - 2007. - Vol. 15. - № 1. - P. 57-70.

14. Окунєва О.В.Генезис концепції внутрішнього маркетингу / О. В. Окунєва // Економічний вісник НТУ КПІ. - 2011. - № 7.

15. Лавлок К. Маркетинг услуг: персонал, технология, стратегия - 4-е изд. / К. Лавлок; Пер. с англ. - М. : Изд. дом «Вильямс», 2005. - 1008 с.

16. Ahmed P. K. Internal Marketing, Tools and Concepts for Customer-Focused Management / P. K. Ahmed, M. Rafiq. - Amsterdam : Elsevier, 2004. - P.4.

17. Gummesson E. The New Marketing - Developing Long-term Interactive Relationships / Gummesson E. // Long Range Planning. 1987. - Vol.20. - № 4. - P.10-20.

18. Harding S. Employer Branding. International Survey Research / S. Harding // Seminar in London. - June, 2004. - [Electronic source]. - Mode of access: www.isrsurveys.com/en/pdf/insight/employerbranding.pdf.

19. Sullivan J. Building An Employment Brand (Part 1 and 2) / J. Sullivan // [Electronic source]. - Mode of access: http://www. drjohnsullivan.com.

20. Амблер Т. Маркетинг і фінансовий результат: нові метрики багатства корпорації / Т. Амблер. - М. : Фінанси і статистика, 2003. - C.167-190.

21. Berthon P. Captivating Company: Dimensions of Attractiveness in Employer Branding / P. Berthon, M. Ewing, L.L. Hah // International Journal of Advertising. - 2005. - Vol.24. - № 2. - P.151-172.

22. Мартін Г. Корпоративні репутації, брендинг і управління персоналом / Г. Мартін, С. Хетрік. - М. : Група ІДТ, 2008. C.246-247.

23. Backhaus K. Conceptualizing and Researching Employer Branding / K. Backhaus, S. Tikoo // Career Development International. 2004. - Vol. 9. - № 5. - P.501-517.

24. Маркетинг. Конспект лекцій / Михалева Е. П. // Аудиокнига. Правообладатель : АРДИС. - Дата выхода : 2010 г. [Электронный ресурс]. - Режим доступа: http://www.litres.ru/e-mihaleva/marketin-konspekt-lekciy/

25. Чанов О. Эволюция брендинга, или чего на самом деле хочет клиент, когда говорит: «Нам нужен бренд» / О. Чанов // [Электронный ресурс]. - Режим доступа: http://marketing.by/main/school/personally/0056865/ . - 11.07.2012.

26. Маркетинг : навч. посіб. / С. І. Чеботар, Я. С. Ларіна, О. П. Луцій, М. Г. Шевчик, Р. І. Буряк, С. М. Боняр та ін. - Київ «Наш час», 2007. - 504 c.

27. Макарова И. К. Управление персоналом : учебник / И. К. Макарова. - М. : Юриспруденция, 2002. - С.32.

28. Barrow S. Turning recruitment advertising into a competitive weapon : paper delivered at the CIPD Annual Conference // S. Barrow. - Harrogate: Chartered Institute of Personnel and Development (CIPD), 1990.

29. Ambler T. The employer brand / T. Ambler, S. Barrow // The Journal of Brand Management. - 1996. -Vol.4. - P.185-206.

30. Knox S. Measuring and Managing Employer Brand Image in the Service Industry / S. Knox, C. Freeman // Journal of Marketing Management. - 2006. - Vol.22. - N7/8. - P.695-716.

31. Engaging Employees through Your Brand // The Conference Board. - New York, NY. - 2001

32. Employer Branding Survey // The Economist. - 2003.

33. Barrow S. The Employer Brand: Bringing the Best of Brand Management to People at Work / S. Barrow, R. Mosley. - Wiley, 2005. $-232 \mathrm{P}$.

34. Employer Branding. [Electronic source]. - Mode of access: http://ru.wikipedia.org/wiki/Employer_branding

Стаття надійшла 18.10.2014

Рецензент: Скопенко Н.С., д.е.н., професор кафедри менеджменту Національного університету харчових технологій. 


\author{
Мокина С.H. \\ аспирант \\ кафедра менеджмента \\ sofia.mokina@gmail.com \\ Национальный университет пищевых технологий \\ ул. Владимирская, 68, г. Киев, Украина, 01601
}

\title{
ЭВОЛЮЦИЯ ФОРМИРОВАНИЯ КОНЦЕПЦИИ БРЕНДА РАБОТОДАТЕЛЯ
}

В статье проведено исследование эволюции формирования концепции бренда работодателя. Определено, что концепция бренда работодателя является междисциплинарной. Автором выделены три основных концепции, в результате развития которых сформировалась концепция бренда работодателя - концепция брендинга, маркетинга и управления персоналом. В статье детально структурирован генезис концепции брендинга работодателя.

Ключевые слова: бренд работодателя, концепция бренда работодателя, понятие бренда работодателя, эволюция бренда работодателя.

\author{
Mokina S. M. \\ postgraduate student \\ Department of Management \\ E-mail: sofia.mokina@gmail.com \\ National University of Food Technologies \\ Volodymyrska street, 68, Kyiv, Ukraine, 01601
}

\section{EVOLUTION OF FORMATION OF EMPLOYER BRAND CONCEPT}

Abstract. The purpose of the article is to study the evolution of formation of employer brand concept. Analysis, systematization and summarizing academic researches of many scientists, the evolution of the concept of employer branding was reviewed, the views of researchers regarding the origin of this concept were systematized.

In the result of research it was determined that the concept of employer branding is interdisciplinary. The author has identified three key concepts, as a result of which formed the concept of employer branding - the concept of branding, marketing and personnel management. In the article the author has made the detailed structure of the genesis of employer branding concept.

According to the goal of article the evolution of formation of employer brand concept was. The concept of employer branding was formed at 90th years of the twentieth century in conditions of highly competitive labor market which is characterized by excess demand for labor over its proposal, the lack of qualified staff, high staff mobility, and reduced staff loyalty to the employer.

Employer brand helps company to be competitive in the job market in such conditions. The concept of formation of employer brand is an interdisciplinary and occurred at the intersection of several concepts - corporate branding, internal branding, internal marketing and human resource management.

Perspective for further research is to study and clarify the conceptual apparatus of the employer brand concept, its functions, methods and tools for formation. Further development of employer brand can lead to replacement of traditional personnel management by more modern talent management based on values.

Keywords: employer brand, employer brand concept, definition of employer brand, evolution of employer brand.

\section{References}

1. Domnin V. N. (2004). Brending: novye technologii v Rossii. SpB: Piter, 250 p.

2. Kotler F., Keller K. (2006). Marketing menedzhment. SpB: Piter, 12 edition, 304 p.

3. Bobrova E. A., Yuldasheva O. U., Okolnishnikova, I. U. (2011). Problemy formirovaniya I razvitiya konkurentosposobnogo brenda $\mathrm{v}$ usloviyah ekonomiki vpechatleniy. Vestnik Udmurtskogo universiteta, 1.

4. Aaker D. (2003). Stvorennya sylnyh brendiv. M.: Vydavnychyy dim Grebinnykova.

5. Aaker D., Joachimsthaler E. (1997). Building Brands without Mass Media. Harvard Business Review January, 75 (1), p. $39-52$.

6. Ries A., Trout J. (2000). Positioning: The Battle for Your Mind. McGraw-Hill; 1 edition.

7. Ged T. (2001). 4D brending: vzlamuvaya korporativnuy kod. SpB: Izdatelstvo: Stokgolmskaya shkola ekonomiki v Sankt-Peterburge, $230 \mathrm{p}$.

8. Ambler T. (2000). Marketing Metrics. Business Strategy Review. Vol. 11, 2, p. 59-66.

9. Bakli P. Dzh. (2008). Globalnaya fabrika: novaya kontseptsya. Rossiyskiy zhurnal menedzhmenta, Vol. 6, 1, 135-154.

10. De Chernatony L. (1999). Brand management through narrowing the gap between brand identity and brand reputation. Journal of Marketing Management. Vol. 15, 1-3, 157-180. C47.

11. De Chernatony L. (2007). Ot videniya brenda do ocenki brenda. Strategicheskiy protses rosta i usileniya brenda. M.: Gruppa IDT,

12. Kucherov D. G. (2009). Brend rabotodateliya: oblast marketinga ili upravleniya liudskimi resursami? Vestnik SPbGU, Vol. $8,3$. 
13. Punjaisri K., Wilkinson A. (2007). The Role of Internal Branding in the Delivery of Employee Brand Promise. Brand Management. Vol. 15, 1, 57-70.

14. Okuneva O. V. (2011). Genezys kontseptsii vnutrishniogo marketyngu. Ekonomichnyy visnyk NTU KPI, 7.

15. Lavlok K. (2005). Marketing uslug: personal, tehnologiya, strategiya. M.: Izd. dom «Viliams», 1008 p.

16. Ahmed P.K., Rafiq M. (2004). Internal Marketing, Tools and Concepts for Customer-Focused Management. Amsterdam: Elsevier, p.4.

17. Gummesson E. (1987). The New Marketing - Developing Long-term Interactive Relationships. Long Range Planning. Vol. 20, 4, 10-20.

18. Harding S. (2004). Employer Branding. International Survey Research. Seminar in London. [Electronic source]. - Mode of access: www.isrsurveys.com/en/pdf/insight/employerbranding.pdf.

19. Sullivan J. Building An Employment Brand (Part 1 and 2). [Electronic source]. - Mode of access: http://www.drjohnsullivan.com.

20. Ambler T. (2003). Marketing I finansovyy rezultat: novye metriki bagatstva korporatsii. M.: Finansy i statistika, 167-190.

21. Berthon P., Ewing M., Hah L. L. (2005). Captivating Company: Dimensions of Attractiveness in Employer Branding. International Journal of Advertising. Vol. 24, 2,151-172.

22. Martin G., Hetric S. (2008). Korportivnaya reputatsiya, brending I upravlenie personalom. M.: Gruppa IDT, $246-247$.

23. Backhaus K., Tikoo S. (2004). Conceptualizing and Researching Employer Branding. Career Development International. Vol. 9 , 5, 501-517.

24. Mihaleva E. P. (2010). Marketing. Konspekt lektsiy. Маркетинг. Audiokniga. Pravoobladatel: ARDIS. http://www.litres.ru/emihaleva/marketin-konspekt-lekciy/

25. Chanov O. (2012). Evoliutsiya brendinga, ili chego na samom dele hochet klient, kogda govorit: «Nam nujen brend». http://marketing.by/main/school/personally/ 0056865/

26. Chebotar S. I., Larina Y. S., Lutsiy O. P., Shevchik M. G., Buriak R. I., Bonyar S. M. (2007). Marketing. Kyiv «Nash chas», 504 p.

27. Makarova I. K. (2002). Upravlenie personalom. M.: Yurisprudentsiya, p. 32.

28. Barrow S. (1990). Turning recruitment advertising into a competitive weapon: paper delivered at the CIPD Annual Conference. Harrogate: Chartered Institute of Personnel and Development (CIPD).

29. Ambler T., Barrow S. (1996). The employer brand. The Journal of Brand Management. Vol. 4, 185-206.

30. Knox S., Freeman C. (2006). Measuring and Managing Employer Brand Image in the Service Industry. Journal of Marketing Management. Vol. 22, 7/8, 695-716.

31. Engaging Employees through Your Brand. (2001). The Conference Board. New York, NY.

32. Employer Branding Survey. (2003). The Economist.

33. Barrow S., Mosley R. (2005). The Employer Brand: Bringing the Best of Brand Management to People at Work. Wiley, $232 \mathrm{p}$.

34. Employer Branding. [Electronic source]. - Mode of access: http://ru.wikipedia.org/wiki/Employer_branding 